\title{
Pola Komunikasi Organisasi Kepemimpinan Strategis di PT TelkomSel
}

\author{
Lucy Pujasari Supratman \\ Program Studi Ilmu Komunikasi Universitas Telkom. \\ Jl Telekomunikasi, Terusan Buah Batu, Bandung 40257, Jawa Barat Telp: 081221524351, \\ Email: doktorlucysupratman@gmail.com
}

\begin{abstract}
The hike of HALO Card, Sympathy, As and Loop users in PT Telkomsel Ambon, MalukuPapua region has continued to grow rapidly. The loyalty of HALO card products user has been excelled other competitors which controls 97\% Market Share in Papua, Maluku. The success of PT Telkomsel Ambon in maintaining HALO card buyer loyalty is due to the strategic role of Manager who applies Strategic Model Leardership throughout 5 Division of PT Telkomsel Ambon. There are Broadband and Digital Sales Division, Sales and Outlet Operations Division, Youth and Community Division, High Valuable Customer Division and Finance Division. This Strategic Leadership Model is done by the Manager in order to create a harmonious relationship between Manager, Supercisor and Staff to boost the highest motivation in building the company. Likewise in facing internal and external conflicts, the manager will easily establish cohesiveness between the Supervisor Divisiona and Staff to get the solution findings together.
\end{abstract}

Keywords: Strategic leadership, manager, organization communication

\begin{abstract}
Abstrak
Peningkatan pengguna produk Kartu HALO, Simpati, As dan Loop di PT Telkomsel Ambon di Wilayah Papua dan Maluku terus berkembang pesat. Loyalitas masyarakat pengguna produk kartu HALO Telkomsel mengungguli produk telekomunikasi pesaing lainnya yang menguasai $97 \%$ market share di Papua Maluku. Keberhasilan PT Telkomsel Ambon mempertahankan loyalitas pembeli kartu HALO dikarenakan peran strategis manager yang mengaplikasikan Model Kepemimpinan Startegis pada seluruh Divisi PT Telkomsel Ambon yang berjumlah 5 Divisi, yaitu Divisi Broadband and Digital Sales, Divisi Sales and Outlet Operations, Divisi Youth and Community, Divisi High Valuable Customer dan Divisi Finance. Model Kepemimpinan Strategis Manager ini dilakukan agar tercipta hubungan yang harmonis antara para supervisor Divisi dan Staff untuk meingkatkan motivasi kebersamaam membangun perusahaan. Begitu juga dalam menghadapi konflik internal maupun eksternal, manager akan dengan mudah membentuk kohesivitas para Supervisor Divisi dan Staff dalam pencarian solusi bersama.
\end{abstract}

Kata kunci: Kepemimpinan strategis, manager, komunikasi organisasi 


\section{Pendahuluan}

Elemen utama dalam terciptanya kepemimpinan komunikasi organisasi yang efektif adalah terjadinya komunikasi dialogis pemimpin dan yang dipimpin. Seorang pemimpin seyogyanya melakukan komunikasi efektif agar menciptakan sinergitas dalam budaya organisasi. Seperti yang dikatakan Supratman (2011), aktivitas dasar manusia tidak akan pernah luput dari komunikasi. Manusia saling berintegrasi satu sama lain dalam kehidupan rumah tangga, pekerjaan, society, millieu, dan dimanapun dia berada. Komunikasi akhirnya menjadi hal yang fardhu bagi manusia untuk menyampaikan seluruh idea-nya. Begitupun halnya bagi suatu organisasi.

Tulisan ini adalah hasil penelitian lanjutan yang dilakukan berdasarkan penelitian terdahulu (Supratman, 2016) tentang "Studi Kasus Model Komunikasi Organisasi Penyelia dalam Membangun Teamwork di Divisi Broadband and Digital Sales". Dalam penelitian sebelumnya, penulis membahas satu Divisi Broadband and Digital Sales dalam sistem komunikasi keorganisasian PT Tekomsel Branch Ambon.

Sedangkan dalam penelitian lanjutan ini, membahas keseluruhan Divisi PT Telkomsel Branch Ambon yang berjumlah 5 Divisi (Divisi Broadband and Digital Sales, Divisi Sales and Outlet Operations, Divisi Youth and Community, Divisi High Valuable Customer dan Divisi Finance) dalam jejaring komunikasi heksagonal organisasi yang seluruh divisi dipimpin oleh seorang manager branch.

Penulis menjelaskan pola kepemimpinan organisasi strategis seorang manajer yang memimpin kelima divisi tersebut. Keberhasilan manajer dalam kepemimpinan ini menghasilkan peningkatan penjualan kartu Halo di PT Telkomsel Ambon sepanjang tahun 2016.

Budaya organisasi PT Telkomsel Branch Ambon memiliki keunikan bila dibandingkan dengan budaya organisasi PT Telkomsel di daerah lain di Indonesia. Tingginya loyalitas konsumen (masyarakat Ambon) yang menggunakan produk
Telkomsel menjadi daya tarik bagi penelitian ini. Prosentase masyarakat Ambon pemakai kartu Halo hampir 90\% dari total keseluruhan penduduk kota Ambon.

"Ambil sensus satu sekolah
saja atau kampus yang sudah
saya survey..seperti universitas
Kristen Indonesia Maluku, semua
mahasiswanya di satu fakultas
pengguna nomor telkomsel", (M
Haidy Zulfikar, apprentice di PT
Telkomsel Ambon, 2015).

Data statistik tentang keberhasilan PT Telkomsel yang dipergunakan oleh masyarakat pengguna jasa layanan produk Telkomsel di wilayah kantor regional UMA (Papua Maluku) juga dipaparkan dalam banyak pemberitaan media. Salah satunya oleh portal berita online detikcom.

“Telkomsel meski sudah
menguasai 97\% pangsa pasar
seluler di Papua-Maluku (PUMA)
masih terus memperkuat wilayah
kekuasaannya dengan membentuk
regional barur sekaligus
meresmikan kantor regionalnya
yang terletak di gedung wilayah
Telkom Papua, Jalan Kayu Batu
Papua. "(Noor, 2014)

Perkembangan pengguna produk Telkomsel di wilayah Papua dan Maluku berkembang pesat. Bahkan saat ini, Telkomsel merupakan operator yang menguasai $97 \%$ market share di Papua Maluku, dimana pencapaian angka tersebut didukung oleh lebih dari 17 ribu outlet yang tersebar hingga ke pelosok dalam membantu pendistribusian produk ke masyarakat.

Keberhasilan PT Telkomsel Ambon memasarkan produk Kartu Halo dikarenakan peran strategis manajer yang memimpin seluruh divisi PT Telkomsel Ambon. Manajer branch PT Telkosmel Ambon memiliki daya pimpin 
strategis dalam mengelola alur komunikasi para divisi agar selalu bersinergi satu sama lain. Setiap divisi dikepalai para supervisor.

Supervisor di tiap divisi memiliki peran untuk mengarahkan staf bagian divisi dalam menjembatani efektifitas keorganisasian tiaptiap divisi. Melalui alur proses komunikasi manajer pada kelima supervisor tersebut, tidak dapat dipungkiri bila seringkali terjadi misunderstanding atau konflik. Manajer harus dapat megelola konflik yang terjadi antar divisi dalam lingkup komunikasi organisasi internal untuk mengarahkan para supervisor dan staf menjadi market leader produk telekomunikasi di kota Ambon.

Supratman (2011) mengatakan bahwa komunikasi yang baik, suatu organisasi dapat berjalan lancar dan berhasil. Begitu pula sebaliknya, kurang atau tidak adanya komunikasi organisasi dapat menimbulkan kesalahpahaman. Misunderstanding tersebut berpengaruh besar bagi kesuksesan organisasional pekerja itu sendiri.

Dalam setiap budaya organisasi, konflik tidak pernah dapat dihindari. Dalam wujudnya konflik dapat berupa perselisihan, kompetisi, ketegangan yang menimbulkan sikap pertentangan di antara dua pihak. Robbins (2003) mengatakan konflik adalah proses interaksi yang terjadi akibat adanya ketidaksesuaian antara dua pendapat (sudut pandang) yang berpengaruh atas pihak-pihak yang terlibat baik pengaruh positif maupun pengaruh negatif.

Bila konflik dibiarkan tanpa mendapatkan solusi, maka permasalahan kedua belah pihak akan semakin meruncing. Hal tersebut berpengaruh pada efektifitas manajemen sumber daya manusia yang melingkungi strukturisasi organisasi tersebut. Menurut Luthans (1995) konflik adalah kondisi yang ditimbulkan oleh kekuatan yang saling bertentangan. Kekuatan ini bersumber pada keinginan manusia. Istilah konflik sendiri diterjemahkan dalam beberapa istilah yaitu perbedaan pendapat, persaingan dan permusuhan.

Eisenhardt (dalam Weingart, 2003) menyodorkan upaya bagi suatu organisasi untuk menciptakan hubungan kerja yang harmoni dalam manajemen konflik. Ia mengatakan bahwa untuk menjaga kinerja seseorang dan kelompok kerjanya pada sebuah organisasi dibutuhkan suatu strategi manajemen konflik melalui strategi manajemen konflik sebagai upaya meningkatkan kinerja lima aktivitas, yaitu menghindari, mengakomodasi, mengkompromikan, mengkompetisikan dan berkolaborasi.

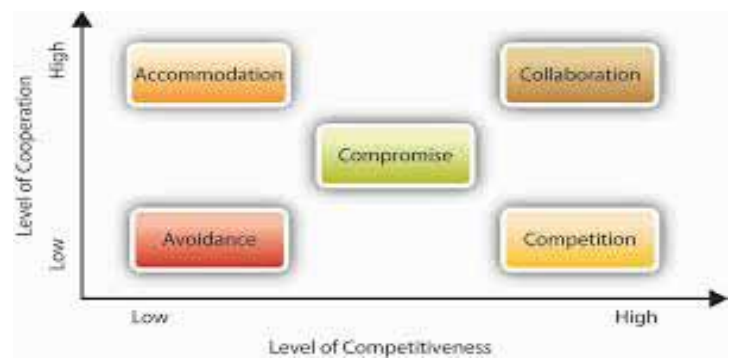

Berikut penjelasan dari bagan strategi manajemen konflik di atas: 1. Menghindari (Avoiding)

Seseorang atau organisasi cenderung untuk menghindari terjadinya konflik. Hal-hal sensitif dan potensial menimbulkan konflik sedapat mungkin dihindari sehingga tidak menimbulkan konflik terbuka.

2. Mengakomodasi (Accomodating)

Anggota tim mengumpulkan dan mengakomodasikan pendapat dan kepentingan pihak yang terlibat konflik, selanjutnya dicari jalan keluar dengan tetap mengutamakan kepentingan pihak lain atas dasar masukan yang diperoleh.

3. Mengkompromikan (Compromising)

Penyelesaian konflik dengan cara melakukan negosiasi terhadap pihak yang berkonflik, sehingga kemudian menghasilkan solusi atas konflik yang sama-sama memuaskan.

4. Berkompetisi (Competing)

Pihak yang berkonflik saling bersaing untuk memenangkan konflik, dan pada akhirnya harus ada pihak yang rela dikorbankan (dikalahkan) kepentingannya demi tercapainya kepentingan pihak lain yang lebih kuat atau yang lebih berkuasa.

5. Mengkolaborasikan (Collaborating) 
Pihak-pihak yang saling bertentangan akan sama-sama memperoleh hasil yang memuaskan, karena mereka justru bekerjasama secara sinergis dalam menyelesaikan persoalan, dengan tetap menghargai kepentingan pihak lain, sehingga kepentingan kedua pihak tercapai.

Komunikasi pimpinan dalam perusahaan merupakan hal utama bagi keefektifitasan kinerja karyawan. Karyawan perusahan tidak dapat mencapai kekompakan dalam teamwork di sebuah divisi bila pimpinan gagal mengkomunikasan visi misi perusahaan. Seorang manager yang membawahi lima divisi PT Telkomsel Ambon memiliki kemampuan manajerial konflik yang baik untuk selalu menggairahkan semangat kesolidan seluruh divisi agar dapat berkontribusi pada perusahaan dan mempertahankan loyalitas konsumen.

Kelima divisi di PT Telkomsel Branch Ambon memiliki masing-masing supervisor, staf dan administrasi yang memiliki tugas, tanggung jawab, serta wewenang yang berbeda sesuai ketentuan yang telah ditentukan oleh pihak Telkomsel Regional Papua Maluku yang berlokasi di Jayapura. Peran manager pada seluruh divisi dengan supervisor yang berada dalam tiap divisi harus dapat mentransfer nilai perusahaan agar dapat menjaga kekompakan setiap divisinya.

Nilai perusahaan yang dikomunikasikan oleh manager haruslah diusung oleh seluruh divisi untuk meningkatkan kesadaran pada kecintaan dan kenyaman bekerja di perusaahan. Transfer nilai tersebut tidak lepas dari peran manager sebagai penentu keefektifan komunikasi organisasi PT Telkomsel Branch Ambon. Seperti yang dikatakan Tangkilisan (2005), bahwa asset organisasi yang paling penting dan harus diperhatikan adalah manusia sebagai anggota sebuah organisasi.

Penelitian ini dibatasi pada ruang lingkup pola komunikasi kepemimpinan strategis manager dalam mengepalai kelima divisi di PT Telkomsel Branch Ambon yang berlokasi di kantor Telkomsel Branch Ambon, Jl. DR. JB. Sitanala No. 9A, Ambon, Indonesia. Tujuan pembatasan penelitian tersebut untuk menghasilkan penelitian yang berfokus pada pola komunikasi pemimpin Manager PT Telkomsel Branch Ambon.

\section{Metode Penelitian}

Penulis menggunakan metode penelitian studi kasus dengan mengelaborasi pola komunikasi manajer PT Telkomsel Branch Ambon dalam memimpin kelima divisi PT Telkomsel Branch Ambon. Lincoln dan Guba (1985) mengemukakan keistimewaan yang dimiliki oleh metode penelitian studi kasus; (1) Studi kasus merupakan sarana utama bagi penelitian emik, yakni menyajikan pandangan subjek yang diteliti, (2) Studi kasus menyajikan uraian menyeluruh yang mirip dengan apa yang dialami pembaca dalam kehidupan seharihari, (3) Studi kasus merupakan sarana efektif untuk menunjukkan hubungan antara peneliti dan responden, (4) Studi kasus memungkinkan penulis dapat menemukan konsistensi internal yang tidak hanya merupakan konsistensi gaya dan konsistensi faktual, tetapi juga menggambarkan keterpercayaan,(5) Studi kasus memberikan 'thick description' yang diperlukan untuk keperluan penilaian atas transferabilitas, (6) Studi kasus terbuka untuk keperluan penilaian pada konteks. Penilaian ini turut berperan dalam pemaknaan fenomena yang terdapat dalam konteks tersebut.

Penelitian studi kasus dibedakan menjadi tiga tipe. Yin (2008) menyebutkan ketiga tipe studi kasus, yaitu: studi kasus eksplanatoris, eksploratoris dan deskriptif. Menurut Yin, terdapat spesifikasi dari ketiga tipe studi kasus. Masing-masing tipe memiliki skema kategori dasaryang didasarkan pada jenis-jenis pertanyaan penelitian. Yin (2008) memaparkan perbedaan dari studi kasus eksplanatoris, eksploratoris dan deskriptif.

Jika pertanyaan penelitian berfokus pada pertanyaan "apakah", maka merupakan 
pertanyaan eksploratoris. Tipe pertanyaan ini dapat digolongkan rasional berguna untuk pengembangan hipotesis. Sedangkan pertanyaanpertanyaan "siapakah" dan "dimanakah" lebih sesuai untuk strategi survei atau analisis rekaman arsip yang dapat digunakan dalam penelitian ekonomi. Strategi ini menguntungkan bila tujuan penelitiannya adalah mendeskiripsikan kejadian atas kelaziman suatu fenomena atau jika berkenaan dengan memprediksi hasil-hasil tertentu.

Sebaliknya, pertanyaan "bagaimana" dan "mengapa" pada dasarnya lebih eksplanatoris dan lebih mengarah ke penggunaan strategi studi kasus. Hal ini disebabkan pertanyaan seperti ini berkenaan dengan kaitan operasional yang menuntut pelacakan waktu tersendiri.

Menentukan tipe pertanyaan penelitian merupakan tahap yang paling penting. Kuncinya adalah memahami bahwa pertanyaan penelitian selalu memiliki substansi, misalnya apakah penelitian memiliki bentuk, apakah saya sedang mempertanyakan "siapakah", "apakah", "di manakah", "mengapakah", atau "bagaimanakah".

Dalam penelitian yang penulis lakukan, tipe pertanyaan yang telah diusung di awal berbentuk "mengapa" dan "bagaimana". Dalam hubungannya dengan hal ini Yin (2008) menegaskan, "pertanyaan "bagaimana" dan "mengapa" lebih cocok untuk studi kasus". Tipe studi kasus yang dipergunakan adalah tipe studi kasus eksplanatoris.

Studi kasus eksplanatoris menuntut pelacakan waktu tertentu. Pelacakan waktu tertentu dituntut karena peneliti telah menjalin relasi yang cukup lama dengan informan untuk keperluan pengumpulan data. Dalam studi kasus, metode terpenting tetap saja bersifat kualitatif..

\section{Hasil Penelitian dan Pembahasan}

Memimpin adalah kemampuan manajemen untuk menciptakan serta mengatur suatu budaya di perusahaan/organisasi. Melalui manajerial kepemimpinan strategis, seorang manager tentu memberikan perhatian penuh pada pengembangan potensi seluruh anggota organisasi (SDM). Perhatian manager tersebut akan menumbuhkan sikap respek dan pengembangan relasi yang baik antara atasanbawahan. Melalui majamemen kepemimpinan, feedback yang diterima oleh perusahaan dari para karyawannya adalah pengabdian sepenuh jiwa, setia dan berdikari untuk terus memajukan perusahaan.

Manager PT Telkomsel Branch Ambon telah mengadopsi peran seorang pemimpin yang penuh kharismatik dalam memimpin seluruh Divisi. Nilai-nilai perusahaan diemban dengan penuh tanggungjawab oleh seluruh anggota perusaahan baik dari tingkat Manager Branch. Supervisor Divisi hingga para staff kelima Divisi

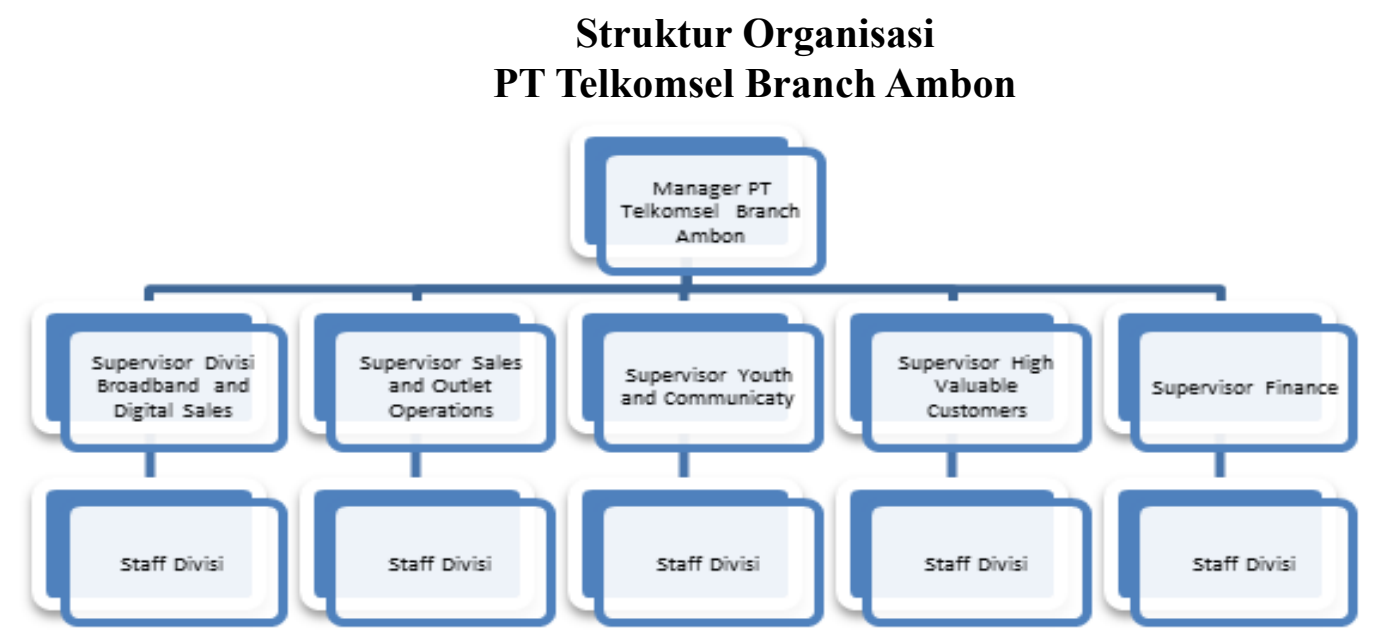

Sumber: Hasil Observasi Lapangan (2016) 
tersebut.

Manager PT Telkomsel Branch Ambon melakukan pola komunikasi kepemimpinan pada setiap divisi yang dikepalai oleh masingmasing supervisor, staff dan administrator. Peran manager PT Telkomsel Branch Ambon, kelima supervisor tiap divisi dan staff memiliki tugas dan tanggung jawab yang berbeda-beda sesuai ketentuan dari Telkomsel Regional Papua Maluku (Jayapura)

\section{Pembagian Kerja Telkomsel Branch Ambon}

1. Manager Branch : bertugas memastikan setiap devisi menjalankan tugas dengan baik Tanggungjawab dan Wewenang : Memastikan pekerjaan pada setiap divisi yang ada di PT. TELKOMSEL BRANCH AMBON berjalan sesuai dengan standar operasional perusahaan dan kebijakan perusahaan

2. Divisi Broadband \& Digital Sales, bertugas antara lain sebagai:
a. Analisa Daerah Operasional : bertanggungjawab menentukan POI (Point of Interest) tiap-tiap WOK, melakukan survey dan analisa coverage $\&$ kualitas network, melaporkan jumlah channel penjualan, termasuk RS, outlet telco, dan MDL menentukan strategi penjualan yang sesuai untuk masing- masing WOK

b. Indirect : bertanggungjawab melakukan Back Checking dan atau tandem selling ke outlet, MDL, open TO, dan Mogi, menghadiri dan mensupervisi briefing pagi di SBO, memberikan saran, motivasi, dan strategi penjualan Bundling, Preload, dan VAS ke sales force, mensupport dan mensupervisi performansi program Sales Broadband dan VAS dan melakukan validasi outlet register di Branch Ambon, mensupervisi performansi penjualan perdana bundling \& Preload dari outlet, menganalisa revenue, recharge, $\mathrm{CB}$ Recharge, $\mathrm{SCN}$, menyusun dan mensupervisi alokasi
Budget Program area, melakukan testing paket internet Telkomsel

c. Direct : bertanggungjawab menentukan lokasi direct selling produk Broadband dan VAS yang dilakukan oleh Mogi, menentukan jumlah Mogi yang diperlukan masing-masing WO, memberikan pengarahan dan edukasi kepada Mogi mengenai produk-produk Broadband dan VAS, mensupervisi kinerja direct selling Mogi untuk penjualan Broadband dan VAS, menyusun dan mensupervisi kerjasama dengan MDL untuk menjual produk Broadband atau VAS yang dibundling dengan device

d. Event : bertanggungjawab mngajukan RAB untuk event dan sponsorship, menyusun timeline event, mensupervisi performa event/ sponsorship, mendesain promosi event/ sponsorship, menyusun dan mengurus kontrak BAK (Berita Acara Kesepakatan) dan PKS (Perjanjian Kerja Sama)

\section{e. Supporting sub departemen dan} divisi lain : bertanggungjawab membantu koordinasi dengan mitra AD dan SOO untuk menyediakan kartu perdana, bundling, ataupun Mkios data untuk dijual di venue event yang diselenggarakan divisi/sub departement lain, memberikan source / aplikasi pendukung.

3. Divisi Sales \& Outlet Operations, bertugas antara lain sebagai :

a. Analisa Potensi Pasar : bertanggungjawab menentukan POI (Point of Interest) tiap-tiap WOK, melakukan survey dan analisa coverage $\&$ kualitas network, melaporkan jumlah channel penjualan, termasuk RS, outlet telco, dan MD dan menentukan strategi penjualan yang sesuai untuk masingmasing WOK

b. Analisa Market Share terhadap Kompetitor : bertanggungjawab 
melaporkan display share, recharge share, dan sales share, menganalisa display share, recharge share, dan sales sharei

c. Operasional, bertanggungjawab melakukan Back Checking dan atau tandem selling ke outlet, MDL, open TO, Mogi dan kantin sekolah/kampus, menghadiri dan mensupervisi briefing pagi di SBO, memberikan saran, motivasi, dan strategi penjualan produk, mensupervisi data CRC (sales in/out) yang dikumpulkan oleh sales force, melaporkan dan mensupervisi distribusi POSMAT ke mitra AD, melaporkan dan mensupervisi distribusi kartu perdana ke mitra $\mathrm{AD}$, melaporkan dan mensupervisi distribusi merchandise ke mitra $\mathrm{AD}$ atau event, menyusun dan mensupervisi alokasi Budget Program area, menyusun program atau paket penjualan kartu perdana untuk outlet/ pelanggan, memantau kinerja mitra AD apakah telah mencapai target KPI, memberikan saran dan strategi yang dapat dipakai mitra AD untuk mencapai KPI yang ditentukan, melaporkan dan menganalisa revenue, recharge, $\mathrm{CB}$ Recharge, SCN.

d. Supporting sub departemen dan divisi lain, bertanggungjawab membantu koordinasi dengan mitra AD untuk menyediakan kartu perdana atau Mkios untuk dijual di venue event yang diselenggarakan divisi/sub departement lain, mensupport dan mensupervisi program Sales Promo

4. Divisi Youth and Community, bertugas antara lain sebagai :

a. Analisa Daerah Operasional : bertanggungjawab melakukan profiling sekolah dan kampus, Menentukan komunitas potensial di masingmasing WOK, Menentukan strategi penjualan yang sesuai untuk masingmasing WOK, Membandingkan tarif kompetitor dengan tarif produk Loop, Melaporkan sales share utk sekolah dan kampumelaporkan sales share utk sekolah dan kampus,

b. Youth \& Community, bertanggungjawab mensupervisi distribusi kartu perdana Loop dari Mitra AD ke outlet, menghadiri dan mensupervisi briefing pagi dan sore di SBO, memberikan saran, motivasi, dan strategi penjualan produk CUG dan LoopMenyusun dan mensupervisi alokasi Budget Program area, melakukan Back Checking dan atau tandem selling ke sekolah dan kampus, mensupervisi Youth Body yang bertanggung jawab terhadap masing-masing WOKMensupervisi program CUG, sales promo, dan Pemenangan Kampus, menentukan lokasi dan jadwal direct selling yang dilakukan oleh Mogi, menentukan jumlah Mogi yang diperlukan masingmasing WOKMemberikan pengarahan dan edukasi kepada Mogi mengenai produk/program yang sedang berjalan, mensupervisi kinerja direct selling Mogi untuk penjualan produk Loop, Performance profiling TSC dan TMC, menyusun dan mensupervisi kerja sama untuk new channel di sekolah dan kampus

c. Event, bertanggungjawab Mengajukan RAB untuk event dan sponsorship, menyusun timeline event, mensupervisi performa event/sponsorship, mendesain promosi event/sponsorship, menyusun dan mengurus kontrak BAK (Berita Acara Kesepakatan) dan PKS (Perjanjian Kerja Sama)

d. Supporting sub departemen dan divisi lain, bertanggungjawab Mensupport divisi lain terkait jalannya event-event Area/Regional 
5. Divisi High Valuable Customers, bertugas sebagai :

a. Analisa daerah operasional

b. Telkomsel poin : bertamggungjawab mensupervisi aktivitas redeem poin Telkomsel yang dilakukan oleh pelanggan, membina dan mensupervisi merchant-merchant Telkomsel Poin, menyusun dan mengurus kontrak BAK (Berita Acara Kesepakatan) dan PKS (Perjanjian Kerja Sama), membuat dan mengajukan keyword untuk kode penukaran Telkomsel Poin, mengontrol distribusi masuk dan keluar merchandise di gudang, mensupervisi dan memberikan edukasi kepada Mogi mengenai Program Telkomsel Poin di event yang berlangsung, memberikan edukasi dan menentukan target redeem Poin, Recharge atau kupon khusus ke SPG di merchant-merchant tertentu

c. Kartu HALO: bertanggungjawab mensupervisi distribusi kartu HALO Retail dari mitra AD ke outlet-outlet, menghadiri dan mensupervisi briefing pagi di SBO, memberikan saran, motivasi, dan strategi penjualan HALO Retail, melakukan Back Checking dan atau tandem selling ke outlet-outlet penjual HALO Retail, melakukan dan mensupervisi aktivasi Kartu HALO, mensupervisi agent sales kartu HALO Reguler, melaporkan performance sales kartu HALO Reguler(SCN), melaporkan performance sales kartu HALO Reguler (RevenuMengurus komplain pelanggan dari shop (aktivasi

d. bertanggungjawab mengajukan RAB untuk event dan sponsorship, menyusun timeline event, mensupervisi performa event/sponsorship, mendesain promosi event/sponsorship, Menyusun dan mengurus kontrak BAK (Berita Acara Kesepakatan) dan PKS (Perjanjian Kerja Sama) e. Supporting sub departemen dan divisi lain, bertanggungjawab Mensupport divisi lain terkait jalannya event-event Area/Regional

\section{Divisi Finance, bertugas sebagai :}

a. Treasury yang bertanggungjawab melakukan Verifikasi \& Validasi invoice Internal \&Ekternal, pengajuan pembayaran invoice Inernal \& Eksternal, pengelolaan Uang Masuk \& Keluar. Membuat laporan keuangan

b. Procurement bertanggungjawab Verifikasi document tender, melaksanakan tender/negosiasi Pengadaan, event atau pekerjaan

c. Werehouse bertanggungjawab melaksanakan fungsi gudang document \& product Telkomsel, Memonitor \& mendistribusikan produk ke Mitra Autoriser Dealer

d. General Affair bertanggungjawab mensupport kebutuhan transportasi operasional, mensupport kebutuhan makan minum karyawan, mensupport kebutuhan Kerumah tanggaan perusahaan

e. Human Relations bertanggungjawab melaksanakan fungsi HR sebagai perpanjangan tangan $\mathrm{HR}$ regional Papua, Maluku di branch Ambon

Strategi kepemimpinan strategis manager PT Telkomsel Branch Ambon adalah dengan menggali permasalahan internal tiap divisi untuk mendapatkan solusi. Manjemen konflik yang dipergunakan untuk mengatasi permalasahan internal adalah teknik obliging. Teknik obliging yang dilakukan manager adalah mengintegrasikan anggota organisasi divisi untuk berkomunikasi yang cair, tanpa sekat dan membuka kesempatan berbicara setiap menghadapi konflik Bila konflik internal dapat diminimalisir, maka tingkat kohesifitas serta gap tiap supervisor divisi akan tinggi.

Hasil akhir dari kohesivitas berimbas pada 
kinerja staf di lapangan untuk merealisasikan target perusahaan guna meningkatkan loyalitas masyarakat pengguna produk Telkomsel. Tjosvold et al (2005) mengungkapkan bahwa organisasi tidak berjalan dengan baik jika di dalamnya tidak ada peran pemimpin sebagai orang yang bertanggung jawab atas organisasi tersebut. Pemimpin itu tidak maksimal dalam melaksanakan tugasnya tanpa adanya bawahan (karyawan) yang selalu berintraksi dan membantunya. Adanya pemimpin dan bawahan (karyawan) tersebut adalah suatu bukti bahwa organisasi dan struktur saling berkaitan. berkomunikasi terbuka. Staf tidak akan merasa segan untuk bersikap komunikatif melaporkan hasil survey di lapangan demi peningkatan layanan konsumen Telkomsel Ambon.

Begitu juga sebaliknya, supervisor divisi sangat terbuka menyampaikan kendala yang dihadapi oleh staf divisi pada manager dalam rapat pimpinan. Pace dan Faules (2006) menjelaskan bahwa pemahaman mengenai kecukupan informasi memberikan petunjuk kepada para anggota organisasi mengenai aspek-aspek organisasi yang merupakan salah satu bagian dari iklim komunikasi organisasi. Komunikasi

\section{Model Komunikasi Terbuka Manager}

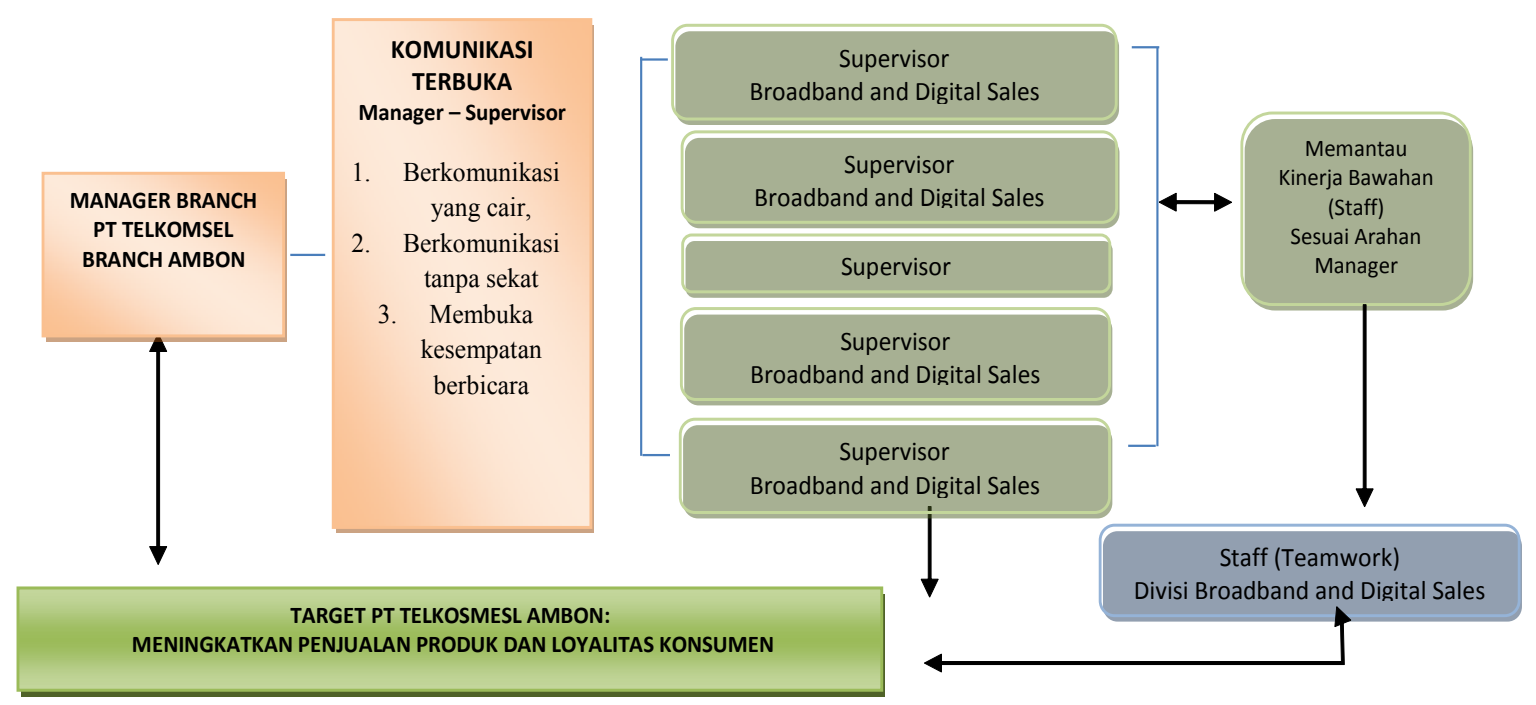

\section{Sumber: Modifikasi Hasil Penelitian}

Manager menjadi acuan bagi para supervisor divisi dalam mensinergikan pesan pada staf divisi yang mengeksekusi keputusan pimpinan di lapangan. Atmosfir keselarasan pesan dibentuk manager melalui keterbukaan komunikasi untuk tetap mencapai keselarasan visi misi sesuai bentuk penugasan setiap anggota organisasi. Keselarasan pemikiran manager, supervisor dan staf divisi diperlukan agar keterbukaan komunikasi serta kerja sama tercipta dalam merealisasikan target PT Telkomsel Branch Ambon. Kegiatan staff di lapangan akan berjalan lancar bila pimipinan divisi dapat adalah sarana simbolis yang dipergunakan manusia untuk memahami serta memengaruhi dunia sosial mereka (organisasi) melalui alur informasi. Manager PT Telkomsel Branch Ambon mengaplikasikan komunikasi terbuka pada seluruh supervisor divisi serta para stafnya. Tujuan komunikasi terbuka dilakukan untuk terciptanya hubungan yang harmonis atasan dan bawahan untuk meningkatkan motivasi kebersamaam membangun perusahaan.

Berikut Model Kepemimpinan Strategis Manager PT Telkomel Branch Ambon: 


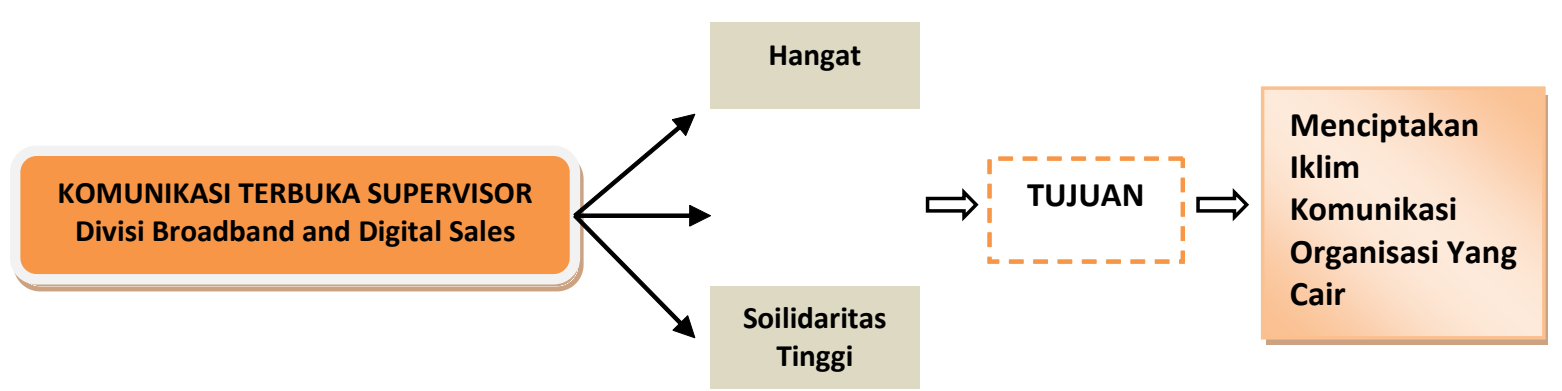

\section{Sumber: Modifikasi Hasil Penelitian}

Kemampuan pemimpin berkomunikasi secara terbuka dapat menciptakan iklim komunikasi yang kondusif bagi suatu organisasi. Begitu juga dalam menghadapi konflik internal maupun eksternal, keterbukaan komunikasi justru mengembangkan kohesivitas atasan dan bawahan dalam pencarian solusi. Serupa dengan pendapat Atkin (2006) yang mengkultuskan sifat dasar keanggotaan dalam dimensi keharmonisan iklim komunikasi organisasi yang efektif. Doktrin tersebut yaitu:

a. Kami percaya bahwa orang pada dasarnya baik.

b. Kami percaya setiap orang memiliki sesuatu yang dapat disumbangkan.

c. Kamipercara bahwa sebuah lingkungan yang jujur dan terbuka dapat memunculkan yang terbaik bagi diri seseorang.

d. Kami mengenali dan menghargai setiap orang sebagai pribadi yang unik.

e. Kami mendorong anda untuk memperlakukan orang lain dengan cara yang sama seperti anda ingin diperlakukan.

Konsep doktrin itu dianut pula oleh gaya memimpin manager PT Telkomsel Branch Ambon yang tidak merasa malu untuk membuka saran serta masukan dari tiap divisi. Begitu juga para supervisor divisi sangat terbuka untuk mengembangkan potensi dirinya memberikan kontribusi pemikiran pada manager. Gaya komunikasi ini berlaku pada pola kepemimpinan supervisor divisi pada para stafnya yang mengadopsi pola kepemimpinan manager. Keterbukaan komunikasi manager menjadi pedoman bagi keberlangsungan organisasi yang solid, karena role model suatu organisasi dimulai dari pimpinan. Peruwujudan kepemimpinan strategis ini merupakan perwujudan seluruh anggota organisasi agar saling mendukung satu sama lain merealisasikan visi misi serta target perusahaan.

\section{Simpulan}

Manager dalam perusahaan harus selalu menciptakan lingkungan organisasi yang hangat untuk menghindari konflik, kesalahpahaman serta gap di antara seluruh anggota organisasi. Manager PT Telkomsel Branch Ambon yang memimpin 5 divisi, yaitu Divisi Broadband and Digital Sales, Divisi Sales and Outlet Operations, Divisi Youth and Community, Divisi High Valuable Customer dan Divisi Finance telah mengaplikasikan model komunikasi terbuka dan kepemimpinan strategis.

Relasi komunikasi yang dilakuan oleh Manager PT Telkomsel Branch Ambon dibina melalui alur komunikasi upward, downward dan horizontal. Komuniasi terbuka antara manajerm divisi dan staf dibina melalui kesederajatan fungsi organisasi untuk menumbuhkan harmoni membangun kemajuan perusahaan bersama. Manager PT Telkomsel Branch Ambon telah membentuk keterbukaan komunikasi dalam struktur formal dan informal keorganisasian dalam pola kepemimpinan strategisnya.

Kepemimpinan dna keterbukaan ini menghasilkan sinergitas kesolidan antar divisi. 
Atmosfir perusahaan yang dibentuk manager PT Telkomsel Branch Ambon menjadi kondusif yang ujungnya dapat meningkatkan produktifitas dan daya kreativitas anggota organisasi. Hal ini terbukti dari tingkat penjualan produk Telkomsel yang betengger di posisi tertinggi di Ambon.

\section{Daftar Pustaka}

Atkin, Douglas. The Culting of Brands: When Customers Become True Believers. USA: Penguin Group Inc. 2006. Lincoln Yvonna S. dan Egon G. Guba. 1985. Naturalistic Inquiry. Beverly Hills: Sage.

Luthans . 1995. Organizational Behavior. Tokyo: Mc Graw-hill Kogakhusa. Ltd Mulyana, Deddy. Metode Penelitian Komunikasi: Contoh-contoh Penelitian Kualitatif Dengan Pendekatan Praktis. 2005. Bandung: Remaja Rosdakarya.

Pace, R. Wayne dan Don F. Faules. Komunikasi Organisasi: Strategi Meningkatkan Kinerja Perusahaan. 2006. Bandung : PT.Remaja Rosdakarya. Robbins, Stephen P. 2003. Perilaku Organisasi. Penerjemah Tim Indeks. Jakarta : PT. Indeks, Gramedia Grup. Rogers, E., and R. Agarwala-Rogers. Communication in Organizations. 1976. New York: Free Press. Supratman, Lucy Pujasari. Komunikasi Terbuka Pimpinan bagi Efektifitas Kinerja Komunikasi Organisasi. 2011. Bandung: Ragam Komunika Vol 5 No1. Kementrian Komunikasi dan Informatika Republik Indonesia, Balai Pengkajian dan Pengembangan Komunikasi dan Informatika. Supratman, Lucy Pujasari dan M Haidy Zulfikar. Studi Kasus tentang Model Komunikasi organisasi supervisor dalam membangun teamwork di divisi broadband \& digital sales. Jurnal Sosioteknologi 15 (2), 213-220, 2016.

Tangkilisan, Hessel Nogi S. 2005. Manajemen Publik. Jakarta: Gramedia Widia Sarana Indonesia
Tjosvold D, Poon M, Yu Z. 2005. Team effectiveness in China: cooperative conflict for relationship building. Human Relations.

Weingart LR, De Dreu CKW. 2003. Task versus relationship conflict, team performance, and team member satisfaction: a meta analysis. Journal of Applied Psychology.

Yin,RobertK.2008. StudiKasus:Desain\&Metode. PT. Raja Grafindo Persada: Jakarta.

\section{Website}

Noor, Achmad Rouzni. Telkomsel Kuasai 97\% Seluler d Papua-Maluku. Jumat, 5 September 2014. Diakses pada bulan Juli 2015. 